\title{
Biometry and pholidosis of Thamnophis scaliger: an atypical example of sexual dimorphism in a natricine snake
}

\author{
Mónica Feriche ${ }^{1, *}$, Senda Reguera ${ }^{1}$, Xavier Santos ${ }^{2,3}$, Estrella Mociño-Deloya ${ }^{1}$, Kirk Setser $^{1}$, Juan M. Pleguezuelos ${ }^{1}$ \\ ${ }^{1}$ Departamento de Zoología, Facultad de Ciencias, Universidad de Granada, Granada, Spain. \\ ${ }^{2}$ Departamento de Biología Animal, Universidad de Barcelona, Barcelona, Spain. \\ ${ }^{3}$ CIBIO, Centro de Investigação em Biodiversidade e Recursos Genéticos, Universidade do Porto, Vairão, Portugal. \\ * Correspondence: Departamento de Zoología, Facultad de Ciencias, Universidad de Granada, E-18071 Granada, Spain. Phone: \\ +34 958 243082, Fax: +34 958 243238, E-mail: monicaf@ugr.es
}

Received: 6 April 2011; received in revised form: 20 July 2011; accepted: 8 August 2011.

Natural-history traits of Thamnophis scaliger (Mesa Central blotched garter snake), a Mexican endemism recently separated from Thamnophis scalaris, are almost unknown. We provide information on biometric and pholidotic traits according to sex for a large sample of individuals, and compare these morphological data with those available for T. scalaris, in order to place the species within the morphological context of the highly diverse genus Thamnophis. Moreover, we examine the adaptive value of sexually dimorphic characters from an evolutionary approach. Thamnophis scaliger appears to have fewer subcaudal and ventral scales than T. scalaris. Our sample also suggests that $T$. scaliger females have larger snout-vent lengths, masses, and body condition indexes (traits related to fecundity) than males, but that males have larger ventral and subcaudal scale numbers, and higher absolute and relative tail lengths (traits related to sexual selection) than females. Ventral and subcaudal scale number is a surrogate of vertebrae number (somites). If females are longer and relatively heavier than males but exhibit a lower number of somites, we suggest that this sexual dimorphism might be driven by the necessity for females of having larger and consequently more robust vertebrae to anchor muscles that have to move a heavier body.

Key words: México; sexual dimorphism; Thamnophis scalaris; Thamnophis scaliger, ventral and subcaudal scale number.

Biometría y folidosis de Thamnophis scaliger: un ejemplo atípico de dimorfismo sexual en un colúbrido natricino. La historia natural de Thamnophis scaliger (serpiente de jardín manchada de Mesa Central), endemismo mexicano recientemente separada de Thamnophis scalaris, es casi desconocida. Presentamos información sobre los rasgos biométricos y folidóticos en función del sexo de una amplia muestra de individuos, y comparamos estos datos con los disponibles para T. scalaris, con el objetivo de situar la especie en el contexto morfológico de un género con una elevada diversidad como Thamnophis. Además indagamos, bajo un enfoque evolutivo, el valor adaptativo de los caracteres sujetos a dimorfismo sexual. Thamnophis scaliger parece tener menos escamas ventrales y subcaudales que $T$. scalaris. Nuestros resultados también apuntan a que las hembras de $T$. scaliger superan a los machos en longitud hocico-cloaca, masa e índice de condición corporal (aspectos relacionados con la fecundidad), mientras que los machos superan a las hembras en número de escamas ventrales y subcaudales y longitudes absoluta y relativa de la cola (aspectos relacionados con la selección sexual). El número de escamas ventrales y subcaudales es un reflejo del número de vértebras (somitos). Sugerimos que la razón por la que las hembras tienen un menor número de somitos que los machos aun siendo más largas y pesadas que éstos puede ser consecuencia de la necesidad de tener vértebras más grandes, y por tanto más robustas, para anclar unos músculos que tienen que mover un cuerpo más pesado.

Key words: Dimorfismo sexual; México; número de escamas ventrales y subcaudales; Thamnophis scalaris; Thamnophis scaliger. 
The genus Thamnophis (American garter snake), distributed throughout North and Central America between $10^{\circ} \mathrm{N}$ and $60^{\circ} \mathrm{N}$ and between $5^{\circ} \mathrm{W}$ and $140^{\circ} \mathrm{W}$, is the most widely-distributed reptile in North America (Rossman et al., 1996). It is the most diverse and studied genus of North American snakes, comprising 31 species (DE QUEIROZ et al., 2002). Information, however, is biased to some species, and while a few of them have been widely studied (more is known about $T$. sirtalis than about any other American snake), very little is known about life histories of many other species in the genus. This unbalanced knowledge prohibits meaningful comparative studies in morphology and natural history from an evolutionary ecology approach. In this sense, understanding phylogenetic relationships among taxa requires knowledge of morphological parameters in all species (REEDER \& WIENS, 1996).

The present study characterizes morphological traits of Thamnophis scaliger, a small, poorly-known species endemic to central Mexico (Rossman et al., 1996), previously considered a subspecies of $T$. scalaris and recently elevated to the rank of species (ROSSMAN et al., 1996; ROSSMAN \& LARAGÓNGORA, 1997). Its position within the genus Thamnophis, however, remains unclear. In a mitochondrial DNA analysis of 29 species within the genus (DE QUEIROZ et al., 2002) each of two specimens of $T$. scaliger from localities separated by approximately $100 \mathrm{~km}$ were placed in different clades. One specimen nested with $T$. scalaris, in agreement with morphological evidence (ROSSMAN \& LARA-GÓNGORA, 1997), while the other nested within the sister group to the clade containing T. exsul and T. errans. This result suggests that $T$. scaliger may be polytypic, and indicates a need for additional data to quantify morphological variability. In view of this confusing situation, we compare morphological data collected from $T$. scaliger with those available for $T$. scalaris in order to place the species within a morphological diversity context in the genus Thamnophis. Moreover, we provide supplementary data for biometric and pholidotic traits according to sex for a large sample of individuals, and examine the adaptive value of some characters from an evolutionary approach. Previously, basic morphological information for $T$. scaliger was provided only by ROSSMAN et al. (1996) and ROSSMAN \& LARA-GÓNGORA (1997).

\section{Materials AND MethodS}

Thamnophis scaliger occurs in the Distrito Federal and the states of México, Aguascalientes and Michoacán (19-22 N, 98$102^{\circ} \mathrm{W}$; elevation $2230-3000 \mathrm{~m}$ above sea level; QuiNTERO-DíAZ et al., 1999; CANSECOMÁrQUEZ et al., 2007) in the northern portion of the Mexican Transverse Volcanic axis and the southern fringe of the Mesa Central. The study area is situated near Atlacomulco, north-western México State $\left(19.70^{\circ} \mathrm{N}\right.$, 99.870W; 2500-2700 $\mathrm{m}$ above sea level), in the highlands of the Central Volcanic Belt of México, near and within the valley of the Río Lerma (Fig. 1). The study area for the sample considered here occupies 74 hectares of pasture for cattle and sheep and fields for various crops. Climate in this area is cool and humid, but while maximum daily temperatures are relatively independent of the season, daily 


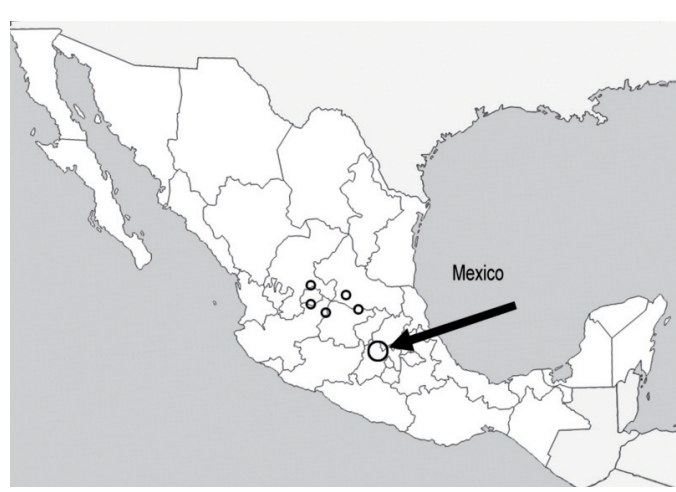

Figure 1: Location of the study area in Mexico State, Mexico (arrow), and known range (circles) of the Mesa Central blotched garter snake, Thamnophis scaliger (modified from Rossman et al., 1996).

minimum temperatures are variable (mean minimum and maximum temperatures are $0.1-20.2^{\circ} \mathrm{C}$ for January and $8.8-21.2^{\circ} \mathrm{C}$ for July). Rainfall is highly seasonal, with $69 \%$ $(570$ of $830 \mathrm{~mm})$ of annual precipitation falling between June and September, and with monthly precipitation during the driest portion of the year (January to May) averaging $3 \%$ of the annual total (Comisión Nacional del Agua station 00015139-Atlacomulco; approximately 5 to $15 \mathrm{~km}$ away from study sites; data recorded from 1961 to 1992). Thamnophis scaliger inhabits pastures near streams and margins of crop fields; human alteration has reduced natural vegetation to river gallery in the valley.

Field sampling was performed daily from June to August 2008 and 2009 by between two and five researchers during morning hours (10:00-13:00), the peak activity period for the species in this area. Snakes were collected above ground or beneath rocks and debris by hand or with tongs and georeferenced by GPS in order to release individuals at the exact point of capture following proces- sing. Samples from two nearby areas, Lagunita $\left(19.90^{\circ} \mathrm{N}, 99.87^{\circ} \mathrm{W}, 2510 \mathrm{~m}\right.$ above seal level) and La Estancia $\left(19.86^{\circ} \mathrm{N}\right.$, $99.80^{\circ} \mathrm{W} ; 2720 \mathrm{~m}$ above sea level) were taken during the same period (although with less sampling effort) in order to find possible areas of syntopy between $T$. scaliger and $T$. scalaris. Syntopy occurred only at $\mathrm{La}$ Estancia, where we found three specimens of T. scaliger and four specimens of T. scalaris.

A total of 161 (71 males, 90 females) $T$. scaliger and four $T$. scalaris were captured. Snakes were anaesthetized in the laboratory (within $20 \mathrm{~km}$ far from any of the study areas) with an approximate dosage of $0.8 \mathrm{ml} / \mathrm{l}$ of isoflurane as described by MociñoDeloya et al. (2009), to obtain reliable biometric and pholidotic measurements (SETSER, 2007). Individuals were marked with a PIT tag (TX148511B model, $8.5 \mathrm{x}$ $2.1 \mathrm{~mm}, 0.1 \mathrm{~g}, 134.2 \mathrm{kHz}$, Destron-Fearing, St. Paul, Minnesota, USA) as described by Mociño-Deloya et al. (2009) before release in order to avoid replication of data. Males and non-gravid females were released within one to four days after capture, whilst gravid females were kept in the laboratory until parturition (between one and two weeks).

We measured snout-vent length and tail length (SVL and TL, respectively, $\pm 1 \mathrm{~mm}$ ), head length and head width (HL and HW, respectively, $\pm 0.1 \mathrm{~mm})$, and body mass $( \pm 0.1 \mathrm{~g}$; gravid females not included in data summaries). We used the Body Condition Index (BCI) to compare differences in body shape between the sexes; this index, widely used in snakes, is calculated from residuals of regression of log body mass on log SVL (BONNET \& NAULLEAU, 1994) in mature individuals of each sex. 
Pholidotic variables measured included the numbers of ventral scales ( $\mathrm{V}$; following DowLING, 1951), subcaudal scale pairs (SC), dorsal scale rows at mid-body (D), and the numbers of preocular scales (PRO), postocular scales (PTO), loreal scales (L), anterior temporal scales (AT), posterior temporal scales (PT), supralabial scales (SPL) and infralabial scales (IFL) on each side of the head (Table 1).

Because of high ontogenetic variation in snake body size, we included only mature individuals in our analysis to evaluate possible sexually-based differences in morphometric variables. Females mature at $267 \mathrm{~mm}$ SVL (SVL of the smallest gravid female; authors' unpublis-

Table 1: Frequencies and percentage of the number of head (both sides) and dorsal scales in a population of Thamnophis scaliger in the Valle del Río Lerma, Atlacomulco, State of Mexico. Abbreviations are defined in the Materials and Methods section.

\begin{tabular}{ccc}
\hline \hline \multirow{2}{*}{ Head characters (N) } & Possible arrangements & $\%$ \\
\hline SPL (70) & $7+7$ & 91.4 \\
& $6+7$ & 7.1 \\
IFL (70) & $6+6$ & 1.4 \\
& $9+9$ & 84.3 \\
PRO (70) & $8+9$ & 14.3 \\
PTO (68) & $8+10$ & 1.4 \\
& $1+1$ & 100 \\
& $3+3$ & 47.1 \\
& $2+2$ & 29.4 \\
L (70) & $2+3$ & 19.1 \\
& $2+1$ & 4.4 \\
AT (69) & $1+1$ & 98.6 \\
& $2+1$ & 1.4 \\
PT (69) & $1+1$ & 97.1 \\
& $1+2$ & 2.9 \\
& $2+2$ & 81.2 \\
& $2+3$ & 11.6 \\
D (113) & $3+3$ & 5.8 \\
& $1+2$ & 1.4 \\
& 19 & 70.8 \\
& 17 & 29.2 \\
\hline
\end{tabular}

hed data); we have no direct data, however, allowing estimation of size at maturity for male T. scaliger. PARKER \& Plummer (1987), after reviewing 19 studies on 10 species of small viviparous colubrids (e.g. T. scaliger), found that, on average, males matured at $87 \%$ of the size of conspecific females. As males reach $84 \%$ of the maximum size of females (see Results), this approach is very similar to estimating sexual maturity in males by utilizing the difference in maximum size between both sexes (SHINE, 1990). Using the generalization calculated by PARKER \& Plummer (1987), we estimated that male T. scaliger matured at $235 \mathrm{~mm}$ SVL.

Variables not normally distributed (SVL of the top decile of each sex) were assessed by nonparametric statistical tests (Mann-Whitney U-test). Tail length, HW and HL varied with body size, and comparisons between sexes were made by analysis of covariance (ANCOVA) with SVL as the covariate. Although numbers of $\mathrm{V}, \mathrm{SC}$, and $\mathrm{V}+\mathrm{SC}$ are not thought to vary over the life of a snake, larger body size has been associated with a greater number of ventral scales in Coronella girondica (SANTOS \& Pleguezuelos, 2003); in these variables, comparisons between sexes were also performed using ANCOVA with SVL as covariate. Comparisons among dorsal scale numbers (D) were assessed using $2 \times 2$ contingency tables.

\section{RESULTS}

Thamnophis scaliger typically exhibit 7 SPL, 9 IFL, 1 PRO, 3 PTO, 1 L, 1 AT, 2 PT, and $19 \mathrm{D}$ (Table 1). The sample of T. scalaris was quite small, but in average, T. scalaris were larger and heavier than T. scaliger and females differed in number of SC: $51-56$ in T. scalaris, 39-48 in T. scaliger (Table 2). 
Table 2: Pholidotic and biometric variables (range, mean $\pm \sigma$ : standard deviations) in populations of Thamnophis scaliger and T. scalaris in the Valle del Río Lerma, Atlacomulco, State of Mexico. For T. scaliger, details for males and females, as well as their statistical comparison, are provided. SVL was compared using ANOVA, while TL, HW, HL, body mass, V, SC, and V + SC were compared using ANCOVAs, with SVL as covariate. For mass comparison the variable was log transformed, and only sexually mature individuals and no pregnant females were considered. See Materials and Methods section for explanations of abbreviations.

\begin{tabular}{|c|c|c|c|c|c|}
\hline \multirow[t]{2}{*}{ Trait } & \multirow[t]{2}{*}{$\%$} & \multicolumn{2}{|c|}{$T$. scaliger } & \multicolumn{2}{|c|}{$T$. scalaris } \\
\hline & & Males & Females & Males & Females \\
\hline \multirow[t]{4}{*}{ SVL $(\mathrm{mm})$} & $\mathrm{N}$ & 68 & 87 & 1 & 3 \\
\hline & Range & $127-369$ & $126-439$ & & $360-500$ \\
\hline & Mean $\pm \sigma$ & $278.4 \pm 70.1$ & $320.2 \pm 72.0$ & 483 & $431.0 \pm 70.0$ \\
\hline & & \multicolumn{2}{|c|}{$\mathrm{F}_{1,153}=13.11 ; P=0.0004$} & & \\
\hline \multirow[t]{4}{*}{$\mathrm{TL}(\mathrm{mm})$} & $\mathrm{N}$ & 62 & 70 & & 3 \\
\hline & Range & $30-93$ & $29-85$ & & $99-125$ \\
\hline & Mean $\pm \sigma$ & $68.2 \pm 19.9$ & $64.8 \pm 14.4$ & & $111.7 \pm 13.0$ \\
\hline & & \multicolumn{2}{|c|}{$\mathrm{F}_{1,130}=178.51 ; P=0.001$} & & \\
\hline \multirow[t]{4}{*}{$\mathrm{HL}(\mathrm{mm})$} & $\mathrm{N}$ & 37 & 37 & & 3 \\
\hline & Range & $8.8-15.5$ & $9.5-17.4$ & & $16.8-22.9$ \\
\hline & Mean $\pm \sigma$ & $12.78 \pm 1.769$ & $13.53 \pm 1.92$ & & $19.2 \pm 3.2$ \\
\hline & & \multicolumn{2}{|c|}{$\mathrm{F}_{1,72}=2.62 ; P=0.110$} & & \\
\hline \multirow[t]{4}{*}{$\mathrm{HW}(\mathrm{mm})$} & $\mathrm{N}$ & 37 & 37 & & 3 \\
\hline & Range & $5.3-11.0$ & $5.3-11.4$ & & $10.7-16.9$ \\
\hline & Mean $\pm \sigma$ & $8.31 \pm 1.317$ & $8.77 \pm 1.293$ & & $12.8 \pm 3.5$ \\
\hline & & \multicolumn{2}{|c|}{$\mathrm{F}_{1,72}=0.67 ; P=0.41$} & & \\
\hline \multirow[t]{4}{*}{ Body mass (g) } & $\mathrm{N}$ & 50 & 40 & 1 & 3 \\
\hline & Range & $10.5-41.7$ & $16.2-70.3$ & & $31.6-72.6$ \\
\hline & Mean $\pm \sigma$ & $23.2 \pm 8.7$ & $36.4 \pm 13.9$ & 67 & $46.7 \pm 22.5$ \\
\hline & & \multicolumn{2}{|c|}{$\mathrm{F}_{1,88}=7.63 ; P=0.007$} & & \\
\hline \multirow[t]{4}{*}{$\mathrm{V}$} & $\mathrm{N}$ & 57 & 71 & 1 & 3 \\
\hline & Range & $134-148$ & $129-145$ & & $138-142$ \\
\hline & Mean $\pm \sigma$ & $141.37 \pm 3.2$ & $135.3 \pm 3.9$ & 140 & $139.7 \pm 2.1$ \\
\hline & & \multicolumn{2}{|c|}{$\mathrm{F}_{1,126}=771.7 ; P<0.0001$} & & \multirow{4}{*}{$\begin{array}{c}3 \\
51-56 \\
53.0 \pm 2.6\end{array}$} \\
\hline \multirow{3}{*}{ SC } & $\mathrm{N}$ & 55 & 63 & & \\
\hline & Range & $48-59$ & $39-48$ & & \\
\hline & Mean $\pm \sigma$ & $53.2 \pm 2.4$ & $44.1 \pm 2.4$ & & \\
\hline \multirow{5}{*}{$V+S C$} & & \multicolumn{2}{|c|}{$\mathrm{F}_{1,116}=389.7 ; P<0.0001$} & & \multirow{5}{*}{$\begin{array}{c}3 \\
190-195 \\
192.7 \pm 2.5\end{array}$} \\
\hline & $\mathrm{N}$ & 39 & 42 & & \\
\hline & Range & $184-204$ & $170-192$ & & \\
\hline & Mean $\pm \sigma$ & $194.2 \pm 4.9$ & $179.5 \pm 5.6$ & & \\
\hline & & \multicolumn{2}{|c|}{$\mathrm{F}_{1,79}=271.9 ; P<0.0001$} & & \\
\hline
\end{tabular}

Adult female $T$. scaliger were larger and heavier than males (Table 2), and differences persisted when we compared SVL from the top decile of each sex (males: $361.9 \pm 5.1$ $\mathrm{mm}$, range 356-369 mm, $\mathrm{N}=7$; females:
$405.2 \pm 13.9 \mathrm{~mm}$, range 395-439 mm, $\mathrm{N}=9$; Mann-Whitney $\mathrm{U}$ test: $\mathrm{Z}=3.334, P<0.001$ ). The longest male measured $369 \mathrm{~mm}$ SVL, and $35 \%$ of the 87 measured females had an SVL greater than this value. In both absolute and 
relative scores, male tail was longer, representing $19.5 \%$ of the total length in this sex $(\mathrm{N}=61)$, whereas in females the tail represented $17.0 \%$ of total length $(\mathrm{N}=70)$. In contrast, when body length was used as covariate, body mass was higher in females than in males (Table 2).

BCI was higher in females $(0.60, \mathrm{~N}=40)$ than in males $(0.53, \mathrm{~N}=49)$, as demonstrated by ANCOVA with sex as factor and SVL as covariate $\left(\mathrm{F}_{1,87}=28.40 ; P<0.0001\right)$. We found no differences between the sexes in relative head length or width (Table 2).

The number of $\mathrm{V}+\mathrm{SC}$ scales after correcting by SVL was higher in males than in females (Table 2; Fig. 2). While ventral scale count did not overlap between sexes, SC counts showed limited overlap (two males and five females [5.4\% of specimens] had 48 pairs of subcaudal scales; Table 2). Males and females differed in the relationship between body length and number of ventral scales: at similar body length, males had more V, SC, and V + SC than did females (Table 2; Fig 2). There were no differences in the number of $\mathrm{D}$ between sexes $\left(\chi^{2}=0\right.$, d.f. $\left.=1, P=0.96\right)$.

\section{DISCUSSION}

\section{Differences between $\mathrm{T}$. scaliger and T. scalaris}

ROSSMAN et al. (1996), ROSSMAN \& LARA-GÓNGORA (1997) and this study demonstrated broad overlap in morphological traits between the two species. However, T. scaliger apparently has a shorter head and a lower number of subcaudal scale pairs than T. scalaris (with no overlap between species when sex is considered), and a shorter relative tail length (the shortest in the genus;

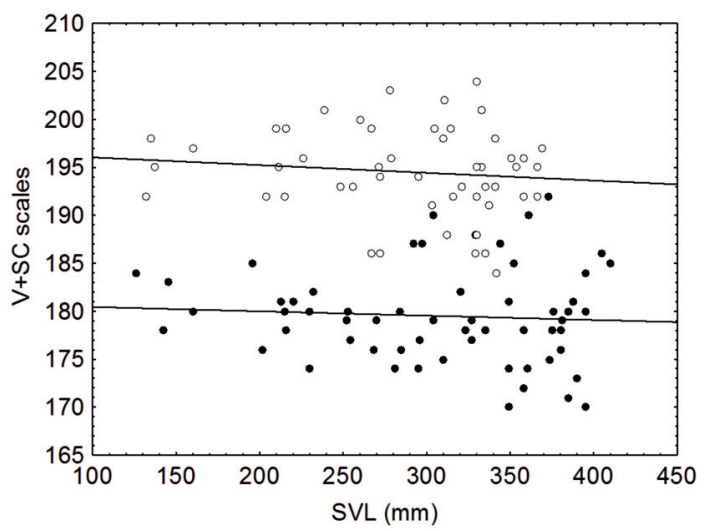

Figure 2: Relationship between ventral + subcaudal $(\mathrm{V}+\mathrm{SC})$ scale count and body size (SVL) by sex in Thamnophis scaliger in the Valle del Río Lerma, Mexico; only individuals with complete tails considered. Females: solid circles; males: open circles. See Table 2 for ANCOVA results.

Rossman et al., 1996). This pronounced tail length difference is due to accommodation for the extremely long hemipenes of $T$. scalaris, which, when invaginated, reach SC pair 27 (ROSSMAN \& LARA-GÓNGORA, 1997).

Thamnophis scaliger and T. scalaris occur in sympatry at only one of the three sampled sites, in La Estancia (16 km NE of the main study area). At this locality, however, the few specimens examined had modal values for biometric and pholidotic traits of the species to which they belong. With due reservations because of the small number of localities we sampled, we suspect these species tend to be allopatric in distribution, but, when in syntopy, each one retains the morphology exclusive to its species. In this sense, the size of the two "scaliger" specimens cited by RAMíREZ-BAUTISTA et al. (1995) near the study area far exceeded the largest snake recorded in our substantial $T$. scaliger sample, and we suggest these specimens were actually $T$. scalaris. 


\section{Sexual dimorphism in T. scaliger}

Body size is one of the most important biological attributes of an organism, and the genus Thamnophis includes terrestrial and aquatic forms with maximum total lengths between $463 \mathrm{~mm}$ and $1626 \mathrm{~mm}$ (Rossman et al., 1996). Thamnophis scaliger is one of the smallest species within the genus, larger only than T. exsul. Within T. scaliger, females achieve greater body length than males, a general characteristic for this and other natricine colubrid snakes (FITCH, 1981). Female snakes that make a significant investment in reproduction tend to attain larger body size than males (SHINE, 1993; BONNET et al., 2000), and T. scaliger is not an exception, as postpartum relative clutch mass is rather high (55\% on average, authors' unpublished data) compared to values from other ovoviviparous species (SEIGEL \& FITCH, 1984).

Male snakes generally have longer tails than females (SHINE et al., 1999) because of the need to accommodate the hemipenes at the base of the tail (KING, 1989). Because of this sexual dimorphism in tail length, males also have a higher number of subcaudal scales than females and, accordingly, 94.2\% (90.6-98.5\%, $\alpha=0.05$ ) of individuals were correctly sexed based solely on this character. Males also had a higher number of ventral scales; while this tendency appears in $89 \%$ of species of Thamnophis (ROSSMAN et al., 1996; SHINE, 2000), it was found in only $20.9 \%$ of 255 various snake species examined by SHINE (2000). Female snakes generally have relatively longer bodies than males to permit accommodation for a large volume of eggs/embryos, which results in a higher number of both trunk vertebrae and ventral scales (fecundity selection; SHINE, 1993). In contrast, a larger proportion of male body somites are devoted to the formation of the tail, which accommodates the hemipenes. Relatively longer tails in males are a generality in snakes (FITCH, 1981); 94\% of species examined by SHINE (2000) showed sexual dimorphism in subcaudal scale number, with higher values in males. Relatively longer tails in males may increase success in mating or male-male rivalry (sexual selection; KING, 1989).

Body length and tail length are highly correlated with the number of ventral and subcaudal scales and subject to selection (SHINE, 2000). In most snake species, the relationship between body length and number of ventral scales is similar in males and females (SHINE, 2000). In species sexually dimorphic in size, this similar relationship permits natural selection to alter body proportions in either or both sexes by varying ventral scale number, and therefore vertebrae number (SHINE, 2000). However, this was not found in the genus Thamnophis (SHINE, 2000) nor in T. scaliger included in this study, since males had more ventral and subcaudal scales (and therefore more vertebrae) per unit body length than did females. Despite having a lower number of ventrals (and subcaudals and, subsequently, ventrals + subcaudals), female T. scaliger have longer bodies than males and higher body condition indexes (at equivalent lengths, females tend to be thicker than males). Assuming the number of ventrals (and the number of subcaudal pairs) to be reflective of the number of vertebrae and that this relationship is universal in snakes (ALEXANDER \& GANS, 1966), we presume that the thicker sex (the female) has fewer vertebrae than the male. According to our presumption, it is plausible to argue that females should have larger and consequently more robust vertebrae to anchor muscles that have to move a heavier body. We did not test this possibility by necropsy or 
X-rays, but the alternative hypothesis - i.e. female vertebrae are not larger but simply longer than male ones - is less plausible. Sexual dimorphism in body thickness has been found in other viviparous snakes and is interpreted as an adaptation to female reproductive function (AUBRET et al., 2002). Although we were unable to test our argument, we suggest the existence of a functional relationship between sexual dimorphism in body shape and vertebrae size in snakes.

We failed to find sexual differences in head shape or any other structures related to prey handling. This result is surprising given the sexual dimorphism detected in other parts of the body. Absence of sexual variation in head morphology may reflect the lack of functional differences in diet between male and female $T$. scaliger, since as far as we know, both sexes forage on the same small prey (earthworms, REGUERA et al., 2011). This conclusion agrees with the sexual dimorphism in head observed in species with diet variation between sexes (VINCENT et al., 2006).

\section{Acknowledgement}

We thank Lic. J. Martínez-Lombarry for generously offering access to his property, and also to P. Sánchez and his family for their warm welcome and assistance throughout the course of our fieldwork. S. Busack kindly improved the content and style of the manuscript. Research was conducted in accordance with SEMARNAT (Mexico) research permits issued to EMD (SGPA/DGVS/05247/08), and was partially funded by the projects A/010196/07 and A/010196/07 of the AECI (Spain), granted to JMP. XS was supported by a post-doctoral grant (SFRH/BPD/73176/2010) from Fundação para a Ciência e a Tecnologia (FCT, Portugal).

\section{REFERENCES}

Alexander, A.A. \& Gans, C. (1966). The pattern of dermal-vertebral correlation in snakes and amphisbaenians. Zoologische Mededelingen 41: 171-190.

Aubret, F; Bonnet, X.; Shine, R. \& LOURDAIS, O. (2002). Fat is sexy for females but not males: the influence of body reserves on reproduction in snakes (Vipera aspis). Hormones and Behavior 42: 135-147. Bonnet, X. \& Naulleau, G. (1994). A body condition index (BCI) in snakes to study reproduction. Comptes Rendus de l'Académie des Sciences 317: 34-41.

Bonnet, X.; Naulleau, G.; Shine, R. \& LOURDAIS, O. (2000). Reproductive versus ecological advantages to larger body size in female snakes, Vipera aspis. Oikos 89: 509-518.

Canseco-Márquez, L.; MendozaQuijano, F. \& Quintero-Díaz, G. (2007). Thamnophis scaliger, In IUCN 2010. IUCN Red List of Threatened Species, v. 2010.3. International Union for Nature Conservation and Natural Resources, Gland, Switzerland. Available at http://www.iucnredlist.org/. Retrieved on $10 / 15 / 2010$.

De Queiroz, A.; Lawson, R. \& LemosEsPinAL, J.A. (2002). Phylogenetic relationships of North American garter snakes (Thamnophis) based on four mitochondrial genes: how much DNA sequence is enough? Molecular Phylogenetics and Evolution 22: 315-329.

Dowling, H.G. (1951). A proposed standard system of counting ventrals in snakes. British Journal of Herpetology 1: 97-99.

FITCH, H.S. (1981). Sexual size differences in reptiles. University of Kansas, Museum of Natural 
History. Miscellaneous Publication 70: 1-72.

KING, R.B. (1989). Sexual dimorphism in snake tail length: sexual selection, natural selection, or morphological constraint? Biological Journal of the Linnean Society 38: 133-154. Mociño-Deloya, E.; SETSER, K.; Pleguezuelos, J.M.; Kardon, A. \& LAZCANO, D. (2009). Cannibalism of nonviable offspring by postparturient Mexican lance-geaded rattlesnake, Crotalus polystictus. Animal Behaviour 77: 145-150.

Parker, W.S. \& Plummer, M.V. (1987). Population Ecology, In R.A. Seigel, J.T. Collins \& S.S. Novak (eds.) Snakes: Ecology and Evolutionary Biology. Macmillan Publishing Company, New York, USA, pp. 253-301.

Quintero-Díaz, G.; VázQuez-Díaz, J. \& SMITH, H.M. (1999). Geographic distribution: Thamnophis scaliger. Herpetological Review 30: 237.

Ramírez-Bautista, A.; GutiérReZ-Mayén, G. \& GonZÁlez-Romero, A. (1995). Clutch size in a community of snakes from the mountains of the valley of Mexico. Herpetological Review 26: 12-13.

REEDER, T.W. \& Wiens, J.J. (1996). Evolution of the lizard family Phrynosomatidae as inferred from diverse types of data. Herpetological Monographs 10: 43-84.

Reguera, S.; Santos, X.; Feriche, M.; Mociño-Deloya, E.; SeTSer, K. \& Pleguezuelos, J.M. (2011). Diet and energetic constraints of an earthworm specialist, the Mesa Central Blotched Garter Snake (Thamnophis scaliger). Canadian Journal of Zoology 89: 1178-1187.

Rossman, D.A. \& Lara-Góngora, G. (1997). Variation in the Mexican garter snake Thamnophis scalaris Cope and the taxonomic status of $T$. scaliger (Jan). Occasional Papers of the Museum of Natural History Science, Louisiana State University 74: 1-14.

Rossman, D.A.; Ford, N.B. \& SeIgel, R.A. (1996). The Garter Snakes: Evolution and Ecology. University of Oklahoma Press, Norman, Oklahoma, USA.

Santos, X. \& Pleguezuelos, J.M. (2003). Variación morfológica en la culebra lisa meridional Coronella girondica (Daudin, 1803) en su área de distribución. Revista Española de Herpetología 17: 53-73.

SEIGEL, R.A. \& Fitch, H.S. (1984). Ecological patterns of relative clutch mass in snakes. Oecologia 61: 293-301.

SETSER, K. (2007). Use of anesthesia increases precision of snake length measurements. Herpetological Review 38: 409-411.

SHINE, R. (1990). Proximate determinants of sexual differences in adult body size. American Naturalist 135: 278-283.

SHINE, R. (1993). Sexual Dimorphism in Snakes, In R.A. Seigel \& J.T. Collins (eds.). Snakes: Ecology and Behavior. McGrawHill, Inc., New York, USA pp. 49-86.

SHINE R. (2000). Vertebral numbers in male and female snakes: the roles of natural, sexual and fecundity selection. Journal of Evolutionary Biology 13: 455-465.

Shine, R.; Olsson, M.M.; MoOre, I.T.; Le MASTER, M.P. \& MASON, R.T. (1999). Why do male snakes have longer tails than females? Proceedings of the Royal Society of London B 266: 2147-2151.

VINCENT, S.E.; DANG, P.D.; HeRREL, A. \& KLEY, N.J. (2006). Morphological integration and adaptation in the snake feeding system: a comparative phylogenetic study. Journal of Evolutionary Biology 19: 1545-1554. 